\title{
DECISION-MAKING IN STRATEGIC MANAGEMENT OF THE PUBLIC SERVICE SYSTEM
}

\author{
Lýdia Gábrišová \\ University of Žilina \\ Univerzitná 8215/1 \\ 01026 Žilina \\ Slovak Republic \\ e-mail: lydia.gabrisova@fri.uniza.sk
}

DOI: $10.13165 /$ PSPO-20-25-08

\begin{abstract}
Let us assume that a certain organization financially supports service centers of public interest, sports, cultural, educational, or other. These centers provide the requirements of customers, who are residents. The organization wants to use its funds efficiently so that the public service system achieves maximum usefulness and fairness to the population. With various possible criteria, we will consider the availability of the inhabitant to the service center and the distance of each inhabitant to the service center to be the main ones.

If the management of the organization had an audit carried out after a few years of operation, it would show that some centers are not sufficiently used, and others not used in terms of capacity. The population of the nearest center is low, and the center is a little used. There would be a possibility to cancel or relocate the service center. On the other hand, some centers do not have sufficient capacity because their services are used by many inhabitants at an acceptable distance. There would be a solution to increase the number of service centers. It is still about using funds efficiently. To resource the unused centers or not to provide services to residents because of the insufficient capacity?

This work deals with the optimization of system by the redistribution of the originally located service centers. I assumed that each center has one or more stations that provide service with a given capacity. Then the service system design task can be modeled as a capacity-limited location task. The XPRESSIVE optimization setting can be used for its implementation. Numerical experiments were performed by using the real data of the Slovak emergency service.
\end{abstract}

Keywords: public service system, requirements of customers, using funds efficiently, capacity-limited location problem

Classification JEL: M12 - Personnel Management

\section{INTRODUCTION}

Our team from Faculty of Informatics at University of Žilina is working in this field for the long time and we have developed several approaches for efficient solution of problems of this type (see e.g. Gábrišová, Janáček, 2014, 2015). There are another group of articles (Kvet, Janáček, 2015, Jánošíková, Gábrišová, Ježek, 2015, Janáček, 2019) devoted to the decomposition strategies for large-scale problems. We developed, implemented and experimentally verified several approximate solution approaches. The part of research of our research group was devoted to different design criteria of public service systems (Peško, Majer, 
2015, Janáček, Gábrišová, 2017, 2019). Real data was from Benchmarks [online] (Szendreyova, 2015).

The solution of the problem is described below.

\section{DESIGN OF PUBLIC SERVICE SYSTEM}

The purpose of public service system is to satisfy the demands of customers by means of several centers, each one of them has one or more service facilities. The geographical locations of centers should be chosen in such way that all services in demand are reachable by general public in acceptable time or at modest distance. Optimal service system should satisfy the "fairness" condition without discrimination of some of customers. When the services provided by service centers are paid by citizens, there is the need of their effective exploitation using the full capacity of all (or almost all) centers.

We do not want to increase the number of existing centers because that involves the additional investment costs (new premises, equipment, service personnel, etc.). We want to increase current effectivity by relocation of existing centers. This is the possibility we will discuss in our work.

Let us assume that the total number of service facilities in centers is known and fixed, and there is the given total number of potential customers. The capacity capability of service facility we will define as the mean number of citizens per facility. The aim of optimization is to relocate centers to geographical locations such that the distance to nearest center for the citizens is as minimal as possible and simultaneously we want to maximally explore the existing capacity of the centers. For the design of improved service system we will use existing informatical tools, as shown in the next sections.

\section{MATHEMATICAL MODEL OF OPTIMIZATION TASK}

Let $I$ be the set of possible locations of service centers and $J$ is the set of locations of potential customers. Let us denote by $d_{i j}$ the known distances between all $i \in I$ and $j \in J$. The services will be realized by chosen centers, each of them having one or more service facilities. The total number of available facilities is $p$, we need to locate them at the locations $i \in I$. For the purpose of determining the demons of each location from set $J$ we use the number of inhabitant's $b_{j}$ (potential customers). The mathematical model of such service system can be formulated as follows: 


$$
\operatorname{Min} \sum_{i \in I} \sum_{j \in J} b_{j} d_{i j} z_{i j}
$$

Subject to:

$$
\begin{aligned}
& \sum_{i \in I} z_{i j}=1 \quad \text { for } j \in J \\
& z_{i j} \leq y_{i} \text { for } i \in I, j \in J \\
& \sum_{i \in I} y_{i} \leq p \\
& \sum_{i \in I} b_{j} z_{i j} \leq a y_{i} \text { for } j \in J \\
& y_{i} \in\{0,1,2,3, \ldots\} \text { for } i \in I \\
& z_{i j} \geq 0 \text { for } i \in I, j \in J
\end{aligned}
$$

This is the well-known type of mathematical optimization problem, the capacitated $p$ median problem. The objective function (1) describes the criterion for minimizing the sum of distances $d_{i j}$ for all customers in location $j$, serviced from the service center $i$. The weight coefficients $b_{j}$ allow us to take into account the number of inhabitants of location $j$. For each service facility, the maximal possible capacity we will denote by $a$. This number a can be interpreted as the mean value of demands or the number of customers per facility (this can be computed easily because we know the total number of inhabitants and the number $p$ of available facilities.

Integer variables $y_{i}$ are used for the number of facilities, allocated in the chosen center in location $i$. Nonnegative variables $z_{i j}$ determine the relative part of demands $b_{j}$ of customers from location $j$, which will be serviced by (nearest) chosen center $i$.

According to conditions (2) each customer will be serviced by exactly one center in location $i$ and the conditions (3) ensure that this center will be chosen at location $i$, i.e. $y_{i} \neq 0$. The condition (4) is here to ascertain that the number of chosen facilities will not exceed the number $p$ of available facilities. The conditions (5) are the capacity constraints. Outputs of solution of the problem are variables $z_{i j}$ and $y_{i}$.

This type of problems is combinatorial difficult (NP-hard), which means that for big sets $I, J$ the computational time can be very long. Problematic with respect to computational time are the constraints with many integer variables. Unfortunately, working with real-world data 
leads typically to big problem instances. In the next section we will describe the solution approach for the design of our service system.

\section{SOLUTION OF OPTIMIZATION PROBLEM}

The analysis of problem shows that we can solve it by using algorithms for well-known transportation problem. For the initial solution we omitted the capacity constraints (5) and choose the centers in all possible locations from set $I$. Our strategy is to sequentially remove some of the centers, namely such one where the summary value of demands is "substantially" lower than the demand values of other centers. The summary demand of the center $j$ is determined by the sum of customer demands $b_{j}$ for all customers assigned to that center. The algorithm, after determining the initial solution, can be described in two steps as follows:

1. Compute the summary demands for all service centers. Remove the center with minimal summary demand. Solve the problem with new centers. Repeat until the number of centers is the desired number $p$.

2. For the center with maximal demand we assign one more facility. Remove the center with minimal summary demand. Solve the problem with new centers as in step 1 . We repeat this process until there are no more than $p$ facilities.

This algorithm appeared to be very effective and its result is to harmonize available capacities $a$ of each facility assigned to chosen center and the summary demands for that center.

\section{REAL-WORLD DATA INSTANCE}

For our computational experiments we will use publicly available real data for inhabited places (cities, towns and villages) of Slovak republic (SR). We know the geographical locations, number of inhabitants, distances between inhabited places. In our case we initially choose both the set $J$ of possible customers and the set of possible locations $I$ as the set of all inhabited places of SR. The number of such places is 2916 , so the problem is realy big and difficult to solve. We choose the decomposition of input data by present regional division of SR to eight selfgoverning regions, which shows to be the effective measure for solution of the sequence of smaller problems. The regions are Bratislava - BA, Banská Bystrica - BB, Košice - KE, Nitra NR, Prešov - PO, Trenčín - TN, Trnava - TT and Žilina - ZA. The original problem was reduced to the solution of 8 smaller partial problems, which can be solved effectively as shown below. 
Input data of problem by regions: summary demand of customer's $j$ (summary number of inhabitant's $b_{j}$ in the hundreds, distances between inhabited places $z_{i j}$ in kilometers according to Benchmarks [online] (Szendreyova, 2015).

Publicly available are also data about actual locations of service centers and the assigned stations of Slovak emergency service in chosen centers. In (Tab. 1) we bring the relevant data about individual regions of SR. In the last column we can see the mean value of customers per one facility (i.e. the ratio of number of inhabitants to the number of service facilities (rounded to nearest integer).

Table 1: Used input data of problem

\begin{tabular}{|c|c|c|c|c|}
\hline Region of SR & $|I|-\begin{array}{c}p \text { number of } \\
\text { cities }\end{array}$ & $\begin{array}{c}p-\text { number of } \\
\text { actual facilities }\end{array}$ & $\begin{array}{c}\text { number of } \\
\text { inhabitants }\end{array}$ & $\begin{array}{c}\text { mumber of inhabitants } \\
\text { per facility }\end{array}$ \\
\hline BA & 87 & 25 & 6063 & 243 \\
\hline TT & 249 & 22 & 5552 & 253 \\
\hline TN & 276 & 26 & 5942 & 229 \\
\hline NR & 350 & 36 & 6896 & 192 \\
\hline ZA & 315 & 36 & 6896 & 144 \\
\hline BB & 515 & 46 & 6601 & 186 \\
\hline KE & 664 & 44 & 8158 & 209 \\
\hline
\end{tabular}

For the main criterion of quality of our optimized system we take the uniformity of distribution of demands among the service facilities. In this real-world problem for the SR it is very likely that we cannot achieve exact uniform distribution because there are different regions with large or smaller density of inhabitants.

Hence it will be better to assess the solution quality by means of some statistical parameter. We choose that parameter as the standard deviation of summary demands for the individual facility $B_{i}=\sum_{j \in J} b_{j} z_{i j}$ from the mean value of demands given by capacity $a$. The values $z_{i j}$ determine the relative part of demands $b_{j}$ of customers from location $j$, which will be serviced by (nearest) chosen center $i$.

In the formula for abovementioned standard deviation:

$$
\sigma=\sqrt{\frac{1}{p-1} \sum_{i \in I_{1}}\left(\frac{B_{i}}{y_{i}}-a\right)^{2}}
$$

$I_{1}$ is the set of centers in our problem solution and $y_{i}$ is the number of facilities belonging to the chosen center in location $i$. 
For the complex assessment of new system design we give also the value of objective function denoted by $U F$ according to formula (1) in kilometers per 100 inhabitants. In second column we give the number of chosen centers denoted by $\left|I_{1}\right|$ and in the third column we give the standard deviation $\sigma$ according to (8). The computed values for individual regions of SR are given in (Tab. 2) and compared with the actual state of system.

For implementation of designed algorithms of problem solution we used Xpress-IVE (Mosel) development environment. Numerical experiments were carried on the PC with 1.6 $\mathrm{GHz}$ Intel Core i7 processor and 8 GB RAM. Computing times of problems for individual regions varied from $0.1 \mathrm{sec}$. for dimensionally smallest task (BA region) to $5.9 \mathrm{sec}$. for largest task (PO region).

Table 2: Comparison of actual state with the solution of problem according to chosen criteria

\begin{tabular}{|c|c|c|c|c|c|c|}
\hline \multirow{2}{*}{$\begin{array}{c}\text { Region of } \\
\text { SR }\end{array}$} & \multicolumn{3}{|c|}{ Actual system } & \multicolumn{3}{c|}{ Designed system } \\
\cline { 2 - 7 } & $\dot{U} F$ & $\left|I_{1}\right|$ & $\sigma$ & $\dot{U} F$ & $\left|I_{1}\right|$ & $\sigma$ \\
\hline BA & 21842 & 14 & 71 & 17405 & 17 & 53 \\
\hline TT & 31582 & 18 & 116 & 32434 & 16 & 57 \\
\hline TN & 26683 & 21 & 134 & 29256 & 17 & 45 \\
\hline NR & 38831 & 27 & 77 & 36223 & 26 & 40 \\
\hline ZA & 31955 & 29 & 94 & 36013 & 22 & 32 \\
\hline BB & 32476 & 36 & 76 & 34906 & 31 & 27 \\
\hline PO & 42740 & 32 & 85 & 45277 & 28 & 40 \\
\hline KE & 36363 & 32 & 127 & 39713 & 27 & 44 \\
\hline
\end{tabular}

\section{CONCLUSION}

For the solution of problem (1) - (7) we applied the approximate approach, described in previous sections. The aim of optimization was to relocate centers to geographical locations such that the distance to nearest center for the citizens is as minimal as possible and simultaneously we want to maximally explore the existing capacity of the centers. The results shown in (Tab. 2) indicate that there is significant improvement in comparison with actual state of the system. The uniformity of demands for the new facilities characterized by the values of standard deviation $\sigma$ is smaller (better) for all regions as comrade with the actual state.

The second criterion of quality of system, namely the value of objective function $U F$ was not improved for some of the regions. This is the consequence of total redesign of system.

Several of the locations of the centers are changed and also the number of centers is different. Another factor which influenced the changes in OF values is the no uniformity of inhabitant's density for the individual regions of SR. 
On the base of the requirements of operator of public service system we designed the mathematical model of problem, implemented and solved it by means of mathematical optimization tools. There is now the need for analysis of results of optimization from financial point of view. New design of the system implies the relocation of centers, discarding some of old centers and to build several new centers. This is accompanied by investment costs for operator if there is a strategically plan to create the service system accessible to general public.

The results of this paper demonstrated the possibilities of effective solution of NP-hard problem described by mathematical model (1) - (7) for design of diverse service systems.

Because of low computational times there is the possibility of use of designed algorithms in real-time decision making situations, e.g. for the choice of existing facilities for the sport, cultural and other events.

\section{REFERENCES}

1. Gábrišová, L., Janáček, J. (2014). Dekompozičný prístup k riešeniu kapacitne obmedzenej lokačnej úlohy. Úlohy diskrétní optimalizace v dopravní praxi: SW podpora rozhodování v inteligentních dopravních systémech. Univerzita Pardubice, Česká republika, 28-37. ISBN 97880-7395-867-1.

2. Gábrišová, L., Janáček, J. (2015). Férovost' vo verejnom obslužnom systéme. In: Optimalizační úlohy v dopravních a logistických systémech a SW podpora rozhodování v inteligentních dopravních systémech: sborník příspěvků: Praha, Albertov, Praha: ČVUT, 102-112. ISBN 97880-01-05853-4.

3. Kvet, M., Janáček, J. (2015). Two phase approach for large public service system design. Mathematical Methods in Economics. University of West Bohemia, Plzeň, 455-460. ISBN 97880-261-0539-8.

4. Jánošíková, L., Gábrišová, L., Ježek, B. (2015). Load balancing location of emergency medical service stations. In: Ekonomie a management: vědecký ekonomický časopis. 18(3), 30-40. ISSN 1212-3609 (online s ISSN 2336-5604).

5. $\quad$ Peško, Š., Majer, T. (2015). Robust p-median problem in changing networks. In: Transport Problems : international scientific journal. 10(3), 125-130. ISSN 1896-0596.

6. Janáček, J., Gábrišová, L. (2017). Collective fairness in emergency system designing. In: SOR'17: proceedings of the 14th international symposium on operational research: Bled, Slovenia, Ljubljana: Slovenian Society Informatika, Section for Operational Research, 135-140. ISBN 978-961-6165-50-1.

7. Gábrišová, L., Janáček, J. (2017). Návrh a porovnanie kritérii kolektívnej férovosti. In: Využitie kvantitatívnych metód vo vedecko-výskumnej činnosti a v praxi XII [elektronický zdroj]: Bratislava: EKONÓM, CD-ROM, [6], ISBN 978-80-225-4392-7.

8. Janáček, J. (2019). Rychlé prohledávání okoli řešení p-lokační úlohy pro zobecněnou disutilitu [electronic]. In: Využitie kvantitatívnych metód vo vedeckovýskumnej činnosti a v praxi. Zborník príspevkov z medzinárodného vedeckého seminára. Bratislava: Vydavatel'stvo EKONÓM, 59-64. [CD-ROM]. ISBN 978-80-225-4617-1.

9. Janáček, J., Gábrišová, L. (2019). User-fair designing emergency service systems [electronic]. In: Transport [print]. 34(4), 499-507. ISSN 1648-3480 (online).

10. Spôsob prístupu: https://journals.vgtu.lt/index.php/Transport/article/view/11312 
11. Jánošíková, L., Kvet, M., Jankovič, P., Gábrišová, L. (2019). An optimization and simulation approach to emergency stations relocation [electronic]. In: Central European Journal of Operations Research [print, online]. 27(3), 737-758. ISSN 1435-246X.

12. Spôsob prístupu: https://link.springer.com/article/10.1007/s10100-019-00612-5

13. Szendreyova, B. (2015). Benchmarks [online] [Accessed May 2016]. Available from: http://frdsa.fri.uniza.sk/ betka/BenchmarksSR.html.

14. FICO ${ }^{\mathrm{TM}}$ Xpress Optimization Suite [online]. Available from: http://www.fico.com.

15. XPRESS-Mosel "User guide”, 2005. Dash Associates, Blisworth, UK.

This article is partially sponsored by projekt VEGA 1/0342/18, Optimal dimensioning of service systems“ and APVV-19-0441, ,Allocation of limited resources to public service systems with conflicting quality criteria“" 